\title{
KAJIAN PROSPEK BISNIS PEMBIBITAN KARET DI PROVINSI SUMATERA SELATAN
}

\author{
Study of Prospective of Rubber Nursery Business in South Sumatera Province \\ Dwi Shinta AGUSTINA*), Lina Fatayati SYARIFA, dan Cicilia NANCY \\ Balai Penelitian Sembawa, Pusat Penelitian Karet \\ Jalan Raya Palembang - P. Balai KM 29 Palembang 30001 Sumatera Selatan \\ *Email : dwishinta_sbw@yahoo.com
}

Diterima : 10 Maret 2016 / Direvisi : 8 Agustus 2016 / Disetujui : 29 Agustus 2016

\begin{abstract}
Since the rubber price had been increased during 2002, it had motivated smallholders to plant rubber. This also encouraged the development of nursery business. However, the decrease of rubber price since 2013 until nowdays has affected the nursery business at the nursery growers' level. The aim of this research was to obtain supply and demand of rubber planting material data in South Sumatera in accordance with the decrease of rubber price. This study was conducted in 2014 by using survey method at the center of rubber nursery in South Sumatera Province included Musi Banyuasin District, Lubuk Linggau City, Prabumulih City, and Banyuasin District. Primary and secondary data were collected. The primary data was collected from the nursery grower, smallholders, and estate. Whereas the secondary data was collected from Estate Agency and the Station of Estate Seed Certification. The data were analysed descriptively. The result of the study showed that the nursery business was still prospective to be developed. Potential of planting material at the nursery grower's level was still large enough considering that land extensification was continued to be conducted. The demand of planting material by smallholders was affected by weather and rubber price. The decrease of rubber price had caused the demand of rubber planting material was also decrease. The demand at large scale nursery grower was still supported by the Government projects.
\end{abstract}

Keywords: Supply; demand; rubber planting material; rubber price; rubber nursery
Abstrak

Meningkatnya harga karet sejak tahun 2002 telah memotivasi petani untuk menanam karet dan mendorong tumbuhnya usaha pembibitan karet oleh penangkar. Namun turunnya harga karet yang terjadi sejak tahun 2013 sampai saat ini turut mempengaruhi kondisi usaha pembibitan di tingkat penangkar. Penelitian ini bertujuan untuk mendapatkan data perkembangan pasokan dan permintaan bibit karet di Provinsi Sumatera Selatan seiring dengan turunnya harga karet yang terjadi saat ini. Penelitian dilaksanakan pada tahun 2014 dengan metode survei di beberapa sentra pembibitan karet di Provinsi Sumatera Selatan yaitu Kabupaten Musi Banyuasin, Kota Lubuk Linggau, Kota Prabumulih, dan Kabupaten Banyuasin. Data yang dikumpulkan meliputi data primer dan data sekunder. Data primer dikumpulkan melalui wawancara dengan penangkar benih, petani karet, dan perusahaan perkebunan. Data sekunder diperoleh dari Dinas Perkebunan dan Balai Pengawasan Sertifikasi Benih Tanaman Perkebunan (BPSBTP). Data yang diperoleh dianalisis secara deskriptif. Dari hasil survei diketahui bahwa usaha pembibitan masih prospektif untuk dikembangkan. Potensi bibit yang tersedia di tingkat penangkar cukup besar mengingat perluasan lahan untuk kebun pembibitan masih terus dilakukan oleh penangkar. Permintaan bibit oleh petani sangat dipengaruhi oleh faktor musim dan harga karet. Turunnya harga karet menyebabkan jumlah permintaan bibit dari petani juga menurun. Usaha pembibitan di tingkat penangkar dengan skala besar pada saat harga karet rendah masih terbantu oleh permintaan dari proyek pemerintah. 
Kata kunci: Pasokan; permintaan; bahan tanam karet; harga karet; pembibitan karet

\section{PENDAHULUAN}

Karet alam merupakan komoditas unggulan di Provinsi Sumatera Selatan (Sumsel), karena merupakan sumber devisa utama dari sub sektor perkebunan dan sumber pendapatan utama bagi jutaan penduduk. Provinsi Sumsel merupakan sentra perkebunan karet rakyat di Indonesia. Pada tahun 2013, luas areal karet di Provinsi Sumsel mencapai 1,2 juta $\mathrm{Ha}$ dengan produksi mencapai 1,1 juta ton dan rata-rata produktivitas mencapai 1410 $\mathrm{kg} / \mathrm{Ha} /$ tahun (Dinas Perkebunan [Disbun] Sumatera Selatan, 2013).

Produksi karet Provinsi Sumsel selama 26 tahun terakhir menunjukkan laju pertumbuhan yang sangat pesat. Apabila pada tahun 1982 ekspor karet Sumsel hanya sekitar 120 ribu ton, maka pada tahun 2012 telah mencapai 1 juta ton (Gabungan Perusahaan Karet Indonesia [GAPKINDO], 2013). Peningkatan produksi dan produktivitas ini merupakan hasil dari berbagai upaya yang dilakukan oleh pemerintah melalui proyek-proyek berbantuan, kemitraan dengan instansiinstansi terkait maupun swadaya petani sendiri. Sampai tahun 2009 pengembangan karet di Provinsi Sumsel telah mencapai 80 ribu Ha dan areal peremajaan adalah 100 ribu Ha (Nancy \& Supriyanto, 2008). Luasan ini meningkat menjadi 1,2 juta Ha pada tahun 2013 dengan areal peremajaan \pm 40 ribu $\mathrm{Ha} /$ tahun dimana 20 ribu $\mathrm{Ha}$ merupakan peremajaan dengan dana dari pemerintah dan 20 ribu Ha merupakan peremajaan swadaya (Bahrin, 2014). Luasnya areal peremajaan dan pengembangan karet ini harus didukung oleh ketersediaan benih bermutu. Dari program peremajaan tahun 2005-2010 terlihat bahwa ketersediaan bahan tanam unggul belum mencukupi kebutuhan (Boerhendhy, Nancy, \& Amypalupy, 2009).

Pengadaan bahan tanam karet bermutu merupakan faktor yang sangat penting, dan merupakan kebutuhan yang mendesak agar target produktivitas yang telah ditetapkan dapat tercapai. Penggunaan bahan tanam tidak bermutu akan menimbulkan kerugian yang sangat besar pada agribisnis karet. Kerugian tersebut akan dialami oleh petani atau pekebun sepanjang tahun sampai tanaman diremajakan. Penggunaan bahan tanam karet tidak bermutu akan menghasilkan produksi $20-50 \%$ lebih rendah dari potensi tanaman yang berasal dari bibit dengan mutu standar (Siagian, Aidi-Daslin, \& Hadi, 2008).

Kebijakan pengembangan karet di Provinsi Sumsel mengacu pada pedoman peremajaan karet nasional yang menggunakan pendekatan partisipatif. Sasaran akhir adalah percepatan peremajaan karet oleh petani dengan menggunakan bibit unggul untuk meningkatkan produktivitas dan pendapatan petani. Membaiknya harga karet yang terjadi sejak tahun 2002 turut mendorong luasnya pengembangan karet di Provinsi Sumsel (Gambar 1). Hal ini turut mendorong berkembangnya usaha pembibitan karet.

Usaha pembibitan tidak selamanya menunjukkan kecenderungan yang meningkat. Kondisi pasokan dan permintaan bibit karet berfluktuasi menurut pergerakan harga karet. Untuk memenuhi kebutuhan bibit, pasokan bibit karet biasanya disediakan oleh Pusat Penelitian Karet, penangkar, perkebunan besar negara dan swasta, pabrik karet remah, dan perusahaan Hutan Tanaman Industri (HTI). Sementara itu, permintaan bibit selama ini berasal dari proyek pengembangan karet oleh pemerintah daerah, petani swadaya, perkebunan besar negara dan swasta, serta perusahaan HTI karet.

Berdasarkan data dari Balai Pengawasan dan Sertifikasi Benih Tanaman Perkebunan (BPSBTP) diketahui bahwa selama 2008-2013 potensi bibit yang dapat disediakan oleh penangkar di Sumsel berfluktuasi (Tabel 1). Hal ini dipengaruhi oleh permintaan pekebun. Penanaman oleh pekebun sangat dipengaruhi oleh fluktuasi harga karet. Krisis global yang terjadi pada tahun 2008 menyebabkan harga karet turun tajam sehingga banyak pesanan bahan tanam dibatalkan. Sebaliknya, tahun 2009/2010 harga karet naik tajam, sehingga permintaan bibit meningkat dan pekebun kesulitan memperoleh bahan tanam karena proses produksi bibit memerlukan waktu minimal satu tahun. 


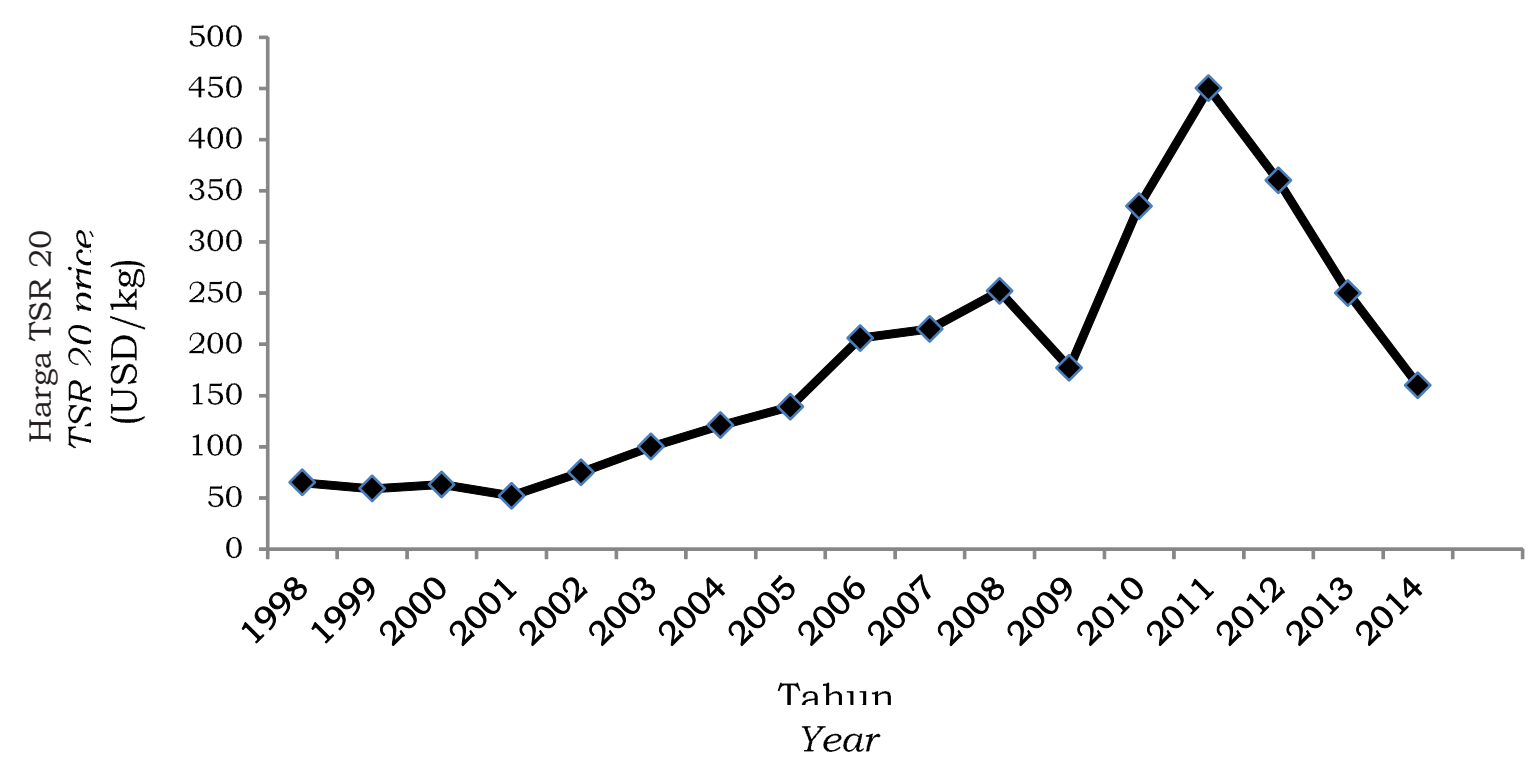

Gambar 1. Fluktuasi harga karet, 1994-2014

Figure 1. Rubber price fluctuation, 1994-2014

Sumber: Singapore Commodity Exchange [SICOM], 2015

Tabel 1. Perkembangan potensi bibit di Sumatera Selatan, 2008-2013

Table 1. The potential development of rubber planting material in South Sumatra, 2008-2013

\begin{tabular}{lrrrrrr}
\hline \multirow{2}{*}{$\begin{array}{c}\text { Jenis bahan tanam } \\
\text { Rubber planting } \\
\text { material type }\end{array}$} & \multicolumn{1}{c}{ Tahun } \\
\cline { 2 - 7 } & 2008 & 2009 & 2010 & 2011 & 2012 & 2013 \\
\hline Polybag & 17.882 .180 & 13.549 .731 & 6.574 .913 & 3.700 .280 & 9.076 .644 & 8.106 .341 \\
Stum Mata Tidur & 1.591 .500 & 2.195 .320 & 252.300 & 894.250 & 1.748 .966 & 2.068 .993 \\
Biji & 47.347 .000 & 48.732 .552 & 65.190 .290 & 43.467 .000 & 69.555 .634 & 72.112 .605 \\
\hline
\end{tabular}

Sumber (Source): BPSBTP, 2014

Usaha pembibitan karet memiliki beberapa kendala dalam pengembangannya, diantaranya : 1) bahan tanam karet tidak dapat disimpan atau distok lama; 2) pasokan bibit oleh penangkar dipengaruhi permintaan bahan tanam oleh para pekebun atau bersifat pesanan; dan 3) karakteristik industri perbenihan karet sangat spesifik terutama dalam hal penyiapan dan transportasi bahan tanam, serta ketersediaan biji karet (Nancy, Lasminingsih, \& Supriadi, 2012).

Permasalahan yang ditemui dalam usaha pembibitan dapat berasal dari pihak produsen bibit terutama dalam hal memenuhi permintaan bahan tanam karet oleh konsumen yang seringkali bersifat mendadak. Selain itu, jadwal penyiapan bibit bisa meleset karena pengaruh iklim, daya kecambah biji rendah, dan kemarau panjang sehingga waktu okulasi tertunda atau okulasi gagal. Permasalahan yang timbul dari sisi konsumen bibit diantaranya tertundanya penyaluran bibit karena lahan untuk penanaman belum siap atau lahan yang akan dijadikan lokasi pembibitan bermasalah. Penundaan pengiriman bahan tanam akan mempengaruhi mutu bahan tanam tersebut (Nancy et al., 2012).

Agar usaha pembibitan dapat tumbuh dengan baik, diperlukan data akurat mengenai kondisi pasokan dan permintaan bibit karet. Data mengenai 
kondisi pasokan dan permintaan bibit karet ini sangat diperlukan untuk melihat prospek bisnis pembibitan di masa mendatang.

\section{BAHAN DAN METODE}

Penelitian dilaksanakan dengan metode survei pada tahun 2014, di lokasi sentra pembibitan karet di Provinsi Sumatera Selatan yaitu Kabupaten Ogan Komering Ulu (OKU) Induk, Kota Lubuk Linggau, Kota Prabumulih, Kabupaten Musi Banyuasin, dan Kabupaten Banyuasin. Data yang dikumpulkan meliputi data primer dan data sekunder. Data primer dikumpulkan dari hasil wawancara dengan para penangkar benih di lokasi sentra pembibitan tersebut. Data sekunder diperoleh dari Dinas Perkebunan Provinsi Sumsel dan Balai Pengawasan Sertifikasi Benih Tanaman Perkebunan (BPSBTP).

Pengambilan sampel menggunakan metode purposive sampling dimana responden dipilih dengan sengaja yaitu petani penangkar bibit karet yang mempunyai Tanda Registrasi Usaha Pembibitan (TRUP). Petani penangkar dikelompokkan berdasarkan skala usaha pembibitan yang dikelola sebagai berikut:

- Kelompok penangkar kecil:

produksi Okulasi Mata Tidur (OMT) $<25.000$ buah dan produksi polybag $<10.000$ buah

- Kelompok penangkar besar:

produksi Okulasi Mata Tidur (OMT) $>100.000$ buah dan produksi polybag $>50.000$ buah

Data untuk kelompok penangkar kecil dikumpulkan dari lima penangkar di Kabupaten Banyuasin dan satu penangkar di Kabupaten Musi Banyuasin. Sementara data untuk kelompok penangkar besar dikumpulkan dari sembilan belas penangkar yang tersebar di Kabupaten Banyuasin (8 orang), Kabupaten Musi Banyuasin (2 orang), Kota Lubuk Linggau (7 orang), dan Kota Prabumulih (2 orang). Pengumpulan data dilakukan dengan mewawancarai responden secara langsung dengan menggunakan kuesioner terstruktur. Beberapa aspek yang diamati meliputi :
Perkembangan produksi bahan tanam karet unggul selama 5 tahun terakhir (label dan non-label)

- Jenis bahan tanam yang dihasilkan (OMT dan polybag)

- Pengalaman sebagai penangkar

- Distribusi bahan tanam (daerah pemasaran bibit)

- Harga jual bahan tanam (IDR)

- Sistem pemasaran bahan tanam

- Konsumen bahan tanam (perorangan dan proyek)

\section{HASIL DAN PEMBAHASAN}

\section{Potensi Pasokan Bibit Karet di Provinsi Sumatera Selatan}

Sumatera Selatan merupakan daerah sentra pembibitan terbesar di Indonesia. Pada kegiatan penelitian ini data potensi pasokan bibit karet dikumpulkan dari beberapa sumber yaitu dari Dinas Perkebunan, penangkar, dan Balai Penelitian Sembawa. Balai Penelitian Sembawa sebagai salah satu lembaga penelitian yang berperan dalam menyediakan bibit karet bagi konsumen bibit.

- Potensi Pasokan Bibit Balai Penelitian Sembawa

Salah satu tugas Balai Penelitian Sembawa adalah menyediakan bahan tanam klon anjuran terbaru bagi para pengguna. Data yang dikumpulkan dari Balai Penelitian Sembawa menunjukkan bahwa selama periode 2010-2013, Balai Penelitian Sembawa menyalurkan bibit 750 ribu sampai 2,3 juta bibit (27\% bibit polybag dan $73 \%$ stum mata tidur). Berdasarkan jenis klonnya, bahan tanam dari Balai Penelitian Sembawa sangat beragam, di antaranya PB 260, BPM 24, RRIC 100, IRR seri 100, PB 217, PB 330, PB 340, BPM 107, BPM 109, PR 300, PR 303, PR 261, RRIM 712, AVROS 2037, GT 1, RRIM 921, dan RRIM 107 (Balai Penelitian Sembawa, 2014). 
Balai Penelitian Sembawa memproduksi bibit sesuai dengan permintaan konsumen. Produksi bibit tahun 2013 meningkat pesat karena tingginya permintaan bibit tahun 2011-2012 akibat meningkatnya harga karet sampai lebih dari USD 4 per kg SIR 20.

Sebagian besar bibit yang dihasilkan oleh Balai Penelitian Sembawa disalurkan kepada petani dan perkebunan besar (Tabel 2). Dari Tabel 2 terlihat bahwa permintaan bibit polybag oleh petani pada tahun 2013 mengalami peningkatan sebesar $16 \%$ dibandingkan dengan permintaan pada tahun 2010. Sebaliknya, untuk perkebunan besar permintaan bahan tanam polybag mengalami penurunan sebesar $44 \%$ dibandingkan tahun 2013. Selanjutnya untuk bahan tanam OMT, permintaan dari petani pada tahun 2010 mengalami penurunan sebesar $72 \%$ dibandingkan tahun 2013. Namun permintaan dari perkebunan besar pada tahun 2013 justru mengalami peningkatan sebesar $153 \%$ dibandingkan tahun 2010. Hal ini

Tabel 2. Perkembangan jumlah bibit yang disalurkan dari Balai Penelitian Sembawa, 2010-2013

Table 2. The fluctuation of rubber planting material that was distributed by Sembawa Research Centre, 2010-2013

\begin{tabular}{|c|c|c|c|c|c|c|c|}
\hline \multirow[b]{2}{*}{$\begin{array}{c}\text { Tahun } \\
\text { Year }\end{array}$} & \multirow{2}{*}{$\begin{array}{c}\text { Jumlah } \\
\text { bibit } \\
\text { polybag } \\
\text { yang } \\
\text { disalurkan } \\
\text { Number of } \\
\text { polybag } \\
\text { distributed }\end{array}$} & \multicolumn{2}{|c|}{$\begin{array}{r}\text { Konsumen } \\
\text { Consumer }\end{array}$} & \multirow{2}{*}{$\begin{array}{c}\text { Jumlah } \\
\text { bibit OMT } \\
\text { yang } \\
\text { disalurkan } \\
\text { Number of } \\
\text { budded } \\
\text { stump } \\
\text { distributed }\end{array}$} & \multicolumn{2}{|c|}{$\begin{array}{c}\text { Konsumen } \\
\text { Consumer }\end{array}$} & \multirow{2}{*}{$\begin{array}{c}\text { Total bibit } \\
\text { yang } \\
\text { disalurkan } \\
\text { Total } \\
\text { planting } \\
\text { material } \\
\text { distributed }\end{array}$} \\
\hline & & $\begin{array}{c}\text { Petani } \\
\text { Smallholders } \\
(\%)\end{array}$ & $\begin{array}{c}\text { Perkebunan } \\
\text { Besar } \\
\text { Estate } \\
(\%)\end{array}$ & & $\begin{array}{c}\text { Petani } \\
\text { Smallholders } \\
(\%)\end{array}$ & $\begin{array}{c}\text { Perkebunan } \\
\text { Besar } \\
\text { Estates } \\
(\%)\end{array}$ & \\
\hline 2010 & 233.970 & 73 & 27 & 516.665 & 68 & 32 & 750.635 \\
\hline 2011 & 179.135 & 70 & 30 & 590.011 & 72 & 28 & 769.146 \\
\hline 2012 & 389.067 & 69 & 31 & 675.780 & 60 & 40 & 1.064 .847 \\
\hline 2013 & 423.412 & 85 & 15 & 1.841 .253 & 19 & 81 & 2.264 .665 \\
\hline
\end{tabular}

menunjukkan bahwa saat ini petani lebih tertarik untuk menanam bibit polybag dibandingkan dengan OMT karena tingkat kematian bibit polybag di lapangan lebih rendah dibandingkan dengan bibit OMT. Perkebunan besar cenderung untuk membeli OMT karena lokasi yang cukup jauh (Kalimantan dan Sulawesi) sehingga memudahkan dalam pengangkutan dan biaya lebih murah.

\section{- Potensi Pasokan Bibit Penangkar}

Untuk memenuhi permintaan bibit yang datang dari petani swadaya dan proyek pemerintah, peran serta penangkar bibit sangat diperlukan. Berkembangnya usaha pembibitan oleh penangkar baik skala besar maupun skala kecil sangat dipengaruhi oleh permintaan bibit dari petani dan proyek pemerintah.
Penangkar bibit di Provinsi Sumatera Selatan berkembang karena tingkat kesadaran petani untuk menanam bibit unggul meningkat seiring dengan proyekproyek pengembangan karet oleh pemerintah dan juga meningkatnya kemampuan petani untuk mengadopsi bibit unggul. Keberhasilan proyek pengembangan karet terdahulu seperti SRDP/PPKR, PIR, proyek parsial (APBD/APBN), program CSR, adanya kebun percontohan yang dibangun di lokasi petani serta tingginya harga karet dewasa ini, telah meningkatkan minat masyarakat untuk menanam bahan tanam okulasi. Apabila pada sekitar tahun 1990 tingkat adopsi bahan tanam unggul oleh petani karet di Sumsel hanya sekitar 40\% (Supriadi et al., 1992), hasil penelitian tahun 2011 yang dilakukan pada 85 desa di Sumsel menunjukkan bahwa tingkat adopsi bahan tanam unggul telah meningkat menjadi 59\% (Syarifa, Agustina, Nancy, \& Supriadi, 2012). 
Di Sumsel, pada tahun 2008 terdapat 126 penangkar yang memiliki TRUP. Namun tahun 2012 jumlah penangkar turun menjadi hanya 42 penangkar (Nancy et al., 2012). Kemudian pada tahun 2013 jumlah ini hanya tinggal 37 penangkar dengan jumlah potensi bibit berdasarkan TRUP hampir mencapai 18,2 juta bibit. Dari sejumlah potensi tersebut, jumlah bibit yang disertifikasi oleh BPSBTP Sumsel pada tahun 2013 berjumlah 10,2 juta bibit sedangkan jumlah biji yang disertifikasi pada tahun 2013 berjumlah 72,1 juta butir. Luas pengembangan entres dari tahun 2009 sampai tahun 2012 mencapai 461 ribu tegakan dengan jenis klon antara lain PB 260 (79,5\%), IRR 39 (13\%), IRR $118(1,97 \%)$, RRIC 100 (1,86\%), BPM 24 (1,52\%), GT 1 (0,43\%), PR 261 (0,71\%), PR $303(0,22 \%)$, dan RRIM 600 $(0,09 \%)$ (BPSBTP, 2014). Entres yang ditanam oleh penangkar biasanya berasal dari Balai Penelitian Sembawa atau bantuan dari Dinas Perkebunan baik di tingkat Provinsi maupun di tingkat Kabupaten.

Dari hasil survei yang dilakukan di tingkat penangkar diketahui saat ini, beberapa penangkar sudah tidak memperpanjang TRUP dengan alasan bahwa pada tahun 2014 terjadi penurunan harga karet yang sangat signifikan sehingga mereka kehilangan pembeli terutama permintaan dari petani yang turun tajam. Hal ini menyebabkan mereka tidak lagi mengusahakan pembibitan karet dan tidak memperpanjang TRUP. Kabupaten Banyuasin merupakan kabupaten sentra pembibitan karet dengan potensi produksi bibit mencapai $50 \%$ dari total potensi yang dimiliki Sumsel (9,1 juta bibit). Selanjutnya Kota Lubuk Linggau dengan potensi produksi bibit sekitar 32\% dari total potensi yang ada (5,8 juta bibit), kemudian Kota Prabumulih, kota Palembang, dan Kabupaten Musi Banyuasin masing-masing $10 \%$ (1,9 juta bibit), $6 \%$ (1,1 juta bibit), dan $2 \%$ (500 ribu bibit) dari total potensi bibit di Provinsi Sumsel.

Proses produksi bahan tanam karet dipengaruhi oleh ketersediaan biji untuk batang bawah dan kebun entres sebagai sumber mata pada proses okulasi. Sebagai sumber biji batang bawah, penangkar menggunakan dua sumber biji, yaitu biji dari Sumatera Utara yang musimnya pada bulan Oktober-Desember dan biji dari Sumatera Selatan pada bulan Februari-Mei. Dari hasil survei di tingkat penangkar diketahui bahwa sebanyak 32\% penangkar menggunakan biji batang bawah yang berasal dari Sumatera Selatan saja, sebanyak $8 \%$ penangkar menggunakan biji batang bawah yang berasal dari Sumatera Utara saja, sedangkan sisanya sebanyak $60 \%$ menggunakan dua sumber biji yaitu dari Sumatera Selatan dan Sumatera Utara.

Berdasarkan skala usahanya, penangkar bibit dikelompokkan menjadi penangkar kecil dan penangkar besar. Kriteria sebagai penangkar kecil apabila dalam produksi bibitnya kurang dari 10 ribu stum atau polybag, dan dalam kegiatannya biasanya dikerjakan oleh tenaga keluarga. Penangkar besar adalah yang mengusahakan bibit dalam skala luas dengan tenaga kerja yang lebih banyak, dan telah memiliki perusahaan yang berbadan hukum, sehingga dapat mengikuti proses tender bibit yang diadakan pemerintah maupun perusahaan swasta. Penangkar skala besar juga bisa terdiri atas beberapa kelompok yang beranggota 10-20 penangkar kecil.

Hasil kegiatan yang dilakukan pada 19 penangkar skala besar dan 6 penangkar skala kecil yang terdapat di beberapa sentra pembibitan di Provinsi Sumsel menunjukkan bahwa produksi bibit yang dihasilkan penangkar dari tahun 2009-2014 cenderung mengalami peningkatan. Hal ini disebabkan penangkar selalu melakukan perluasan kebun bibit batang bawah dan kebun entres. Kondisi kebun entres dan kebun batang bawah penangkar ditampilkan pada Gambar 2.

Para penangkar di Sumsel awalnya membuat pembibitan dalam skala kecil, dan beberapa di antaranya menjadi besar yang kemudian membentuk perusahaan berbadan hukum (PT atau CV), agar dapat menjadi pemasok bibit untuk proyek pemerintah. Pengalaman mengelola usaha pembibitan berkisar antara 3-28 tahun dengan rata-rata selama 14 tahun. Data ini menunjukkan bahwa masing-masing penangkar memiliki pengalaman mengelola kebun pembibitan relatif lama dan masih berlangsung sampai saat ini. 

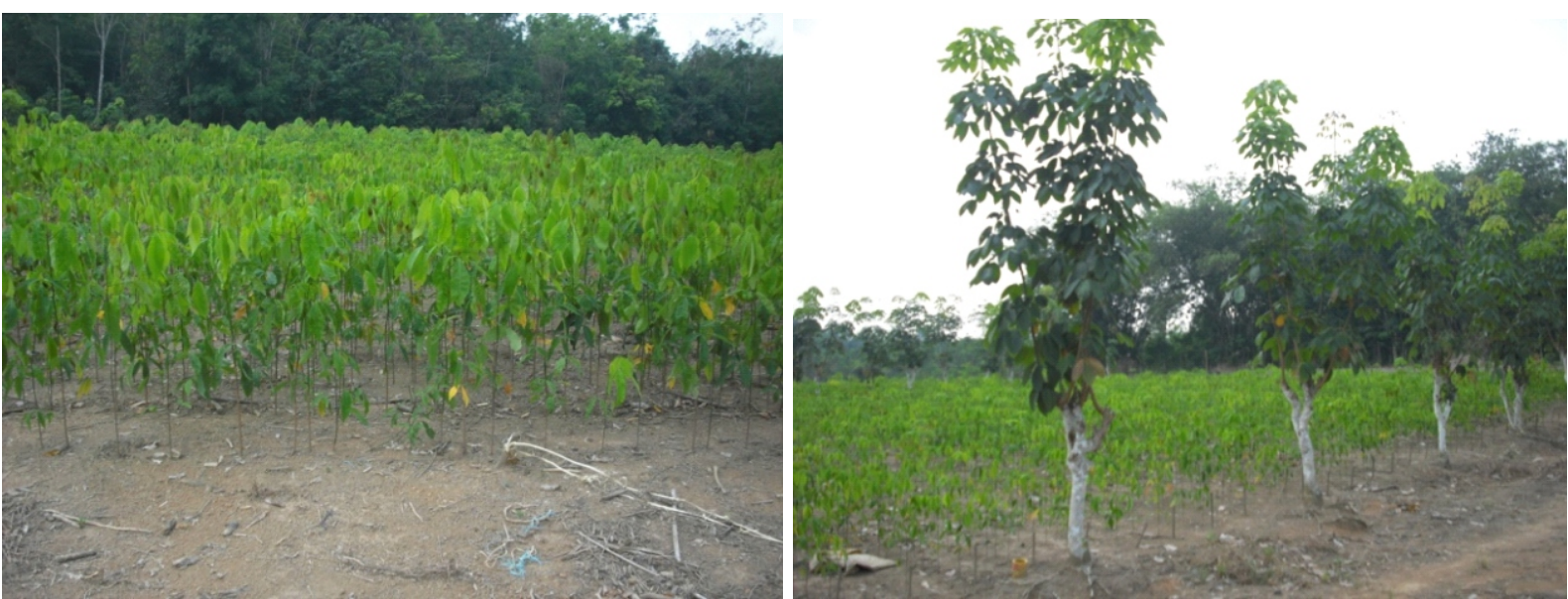

Gambar 2. Penampilan kebun batang bawah dan kebun entres di tingkat penangkar

Figure 2. Performance of rootstock and budwood gardens at the nursery grower's level

Dari hasil survei diketahui bahwa penangkar masih akan melanjutkan usaha pembibitan meskipun harga karet saat ini sedang mengalami penurunan. Para penangkar optimis bahwa usaha pembibitan masih memiliki prospek sampai beberapa tahun ke depan. Menurut penangkar permintaan bibit masih akan ada karena karet merupakan komoditi utama di Provinsi Sumsel. Selain itu mereka juga telah menyatu dengan usaha pembibitan sehingga sulit bagi mereka untuk berkecimpung dalam usaha yang lain.

- Potensi Permintaan Bibit Karet di Provinsi Sumatera Selatan

Permintaan bibit karet berupa stum atau okulasi mata tidur dan polybag biasanya berasal dari petani swadaya, perusahaan perkebunan, dan proyek pemerintah. Berdasarkan data Dinas Perkebunan Provinsi Sumatera Selatan (2012) diketahui bahwa target peremajaan di Sumatera Selatan adalah 40 ribu $\mathrm{Ha}$ /tahun dimana 20 ribu Ha merupakan peremajaan melalui proyek pemerintah dan 20 ribu $\mathrm{Ha}$ lagi merupakan peremajaan yang dilakukan petani swadaya. Dari total luasan peremajaan yang didanai oleh proyek pemerintah, seluas $\pm 1.500 \mathrm{Ha} /$ tahun didanai dengan APBN, $\pm 3.000 \mathrm{Ha} /$ tahun didanai dengan APBD I, dan \pm 7.500 $\mathrm{Ha} /$ tahun didanai dengan APBD II. Dari data tersebut diketahui bahwa masih ada \pm 8.000 $\mathrm{Ha} /$ tahun yang belum diremajakan (Bahrin, 2014). Jika diasumsikan kebutuhan bibit per Ha sebanyak 600 polybag, maka untuk peremajaan yang didanai oleh proyek pemerintah di Sumatera Selatan dibutuhkan sekitar 7,2 juta bibit per tahun. Jumlah ini belum termasuk kebutuhan bibit untuk petani swadaya.

Permintaan bibit di tingkat penangkar umumnya berupa bahan tanam polybag. Sepanjang tahun 2009-2014, potensi bibit yang tersedia di tingkat penangkar berkisar antara 2,6-11 juta. Dari sejumlah potensi tersebut, dapat disalurkan bibit sebanyak 72 - 99\%. Hal ini menunjukkan bahwa rata-rata bibit yang dihasilkan oleh penangkar hampir tersalur semuanya. Data yang diperoleh dari penangkar diketahui bahwa pada tahun 2011 terdapat kekurangan bibit dimana jumlah permintaan lebih besar dibandingkan produksi di tingkat penangkar karena lonjakan permintaan yang cukup besar. Permintaan bibit polybag di tingkat penangkar rata-rata $97 \%$, sedangkan permintaan bibit OMT hanya sekitar 3\%. Penampilan bibit yang dihasilkan penangkar ditampilkan pada Gambar 3.

Untuk penangkar skala kecil, permintaan bibit seluruhnya berasal dari petani swadaya sedangkan untuk penangkar skala besar permintaan berasal dari petani swadaya, proyek pemerintah, perusahaan perkebunan, dan dari perusahaan HTI. Secara keseluruhan, penurunan harga karet tidak mempengaruhi permintaan bibit di tingkat penangkar skala besar karena mereka masih memiliki permintaan terutama dari proyek 

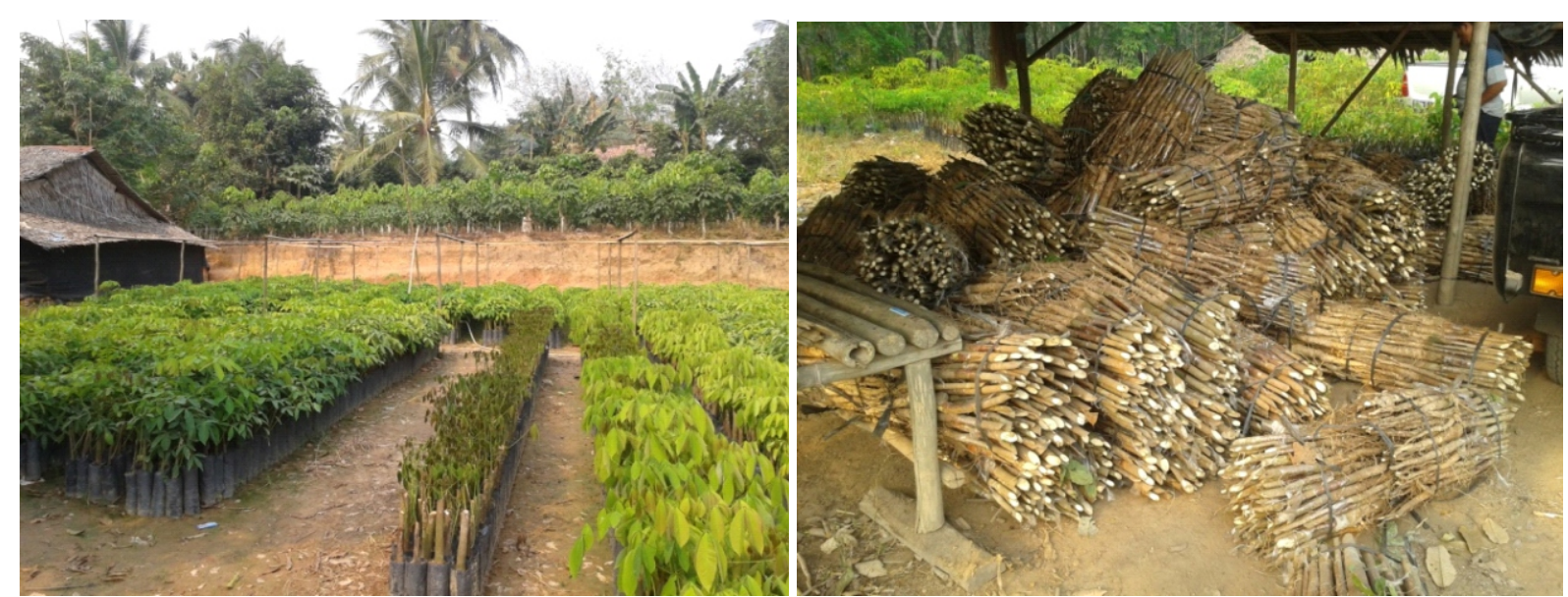

Gambar 3. Penampilan bibit polybag dan stum mata tidur di tingkat penangkar

Figure 3. Performance of polybag and budded stump at the nursery grower's level

pemerintah dan perkebunan swasta. Namun, untuk penangkar skala kecil, penurunan harga karet yang terjadi saat ini sangat berpengaruh terhadap permintaan bibit. Beberapa penangkar skala kecil seperti di daerah Lubuk Linggau dan Prabumulih tidak lagi mengusahakan bibit karena tidak adanya pembeli.

Permintaan bibit oleh petani akibat menurunnya harga karet sangat signifikan baik di tingkat penangkar kecil maupun di tingkat penangkar besar. Dari hasil survei diketahui bahwa komposisi permintaan bibit dari petani, proyek pemerintah, perkebunan swasta pada penangkar besar untuk periode 2011-2012 (kondisi harga karet tinggi) adalah $36,7 \%$ permintaan dari petani, $61,7 \%$ permintaan dari proyek, dan $1,7 \%$ permintaan dari perusahaan perkebunan. Sementara itu, untuk periode 2013-2014 pada saat harga karet rendah adalah 9,4\% permintaan dari petani, 83,1\% permintaan dari proyek, dan $6,7 \%$ permintaan dari perkebunan swasta. Untuk penangkar skala kecil, permintaan bibit dari petani pada tahun 2013-2014 menurun menjadi 49\% dibandingkan pada saat kondisi harga karet tinggi pada tahun 2011-2012. Komposisi permintaan di tingkat penangkar pada kondisi harga karet tinggi dan harga karet rendah ditampilkan pada Tabel 3.

\section{Rantai Pemasaran Bibit Karet}

Dari hasil kegiatan survei diketahui bahwa ada beberapa pola rantai pemasaran bibit karet yang berkembang (Gambar 4) yaitu: a. Penangkar kecil langsung menjual bibit karet kepada petani swadaya

b. Penangkar besar langsung menjual bibit karet kepada petani swadaya

c. Penangkar besar mengikuti tender proyek pemerintah, kemudian bibit disalurkan kepada petani proyek pemerintah

d. Kontraktor atau orang yang memiliki modal besar atau badan usaha yang ikut tender pada proyek pemerintah, kemudian penangkar besar sebagai penjamin pasokan bagi kontraktor. Selanjutnya bibit dari penangkar besar disalurkan kepada petani proyek pemerintah.

Daerah pemasaran bibit meliputi wilayah Provinsi Sumatera Selatan (48\%), Provinsi Jambi (15\%), serta wilayah luar Provinsi Sumatera Selatan (37\%). Pemasaran bibit untuk wilayah Provinsi Sumatera Selatan meliputi Kabupaten Musi Banyuasin (30\%), Kabupaten OKI $(29,2 \%)$, Kabupaten OKU Timur (8,6\%), Kabupaten Muara Enim $(8,4 \%)$, Kabupaten Musi Rawas $(4,9 \%)$, Lahat $(4,3 \%)$, Ogan Ilir $(3,6 \%)$, Lubuk Linggau $(3,2 \%)$, Banyuasin $(3,2 \%)$, Provinsi Sumsel $(1,7 \%)$, Prabumulih $(0,7 \%)$, OKU Selatan $(0,7 \%)$, Pagar Alam (0,6\%), Empat Lawang $(0,4 \%)$, dan Kabupaten OKU Induk $(0,3 \%)$. Untuk wilayah luar Provinsi Sumatera Selatan, daerah pemasaran bibit meliputi Provinsi Riau (30,7\%), Bangka Belitung $(27,5 \%)$, Sumatera Barat $(17,6 \%)$, Jawa Barat $(7,7 \%)$, Lampung $(6,7 \%)$, Kepulauan Riau (5,9\%), Jawa Tengah $(3,3 \%)$, dan Bengkulu (0,5\%). 
Tabel 3. Komposisi permintaan bibit karet di tingkat penangkar pada kondisi harga karet tinggi dan harga karet rendah

Table 3. Composition of rubber planting material demand at the nursery grower's level in a condition of high and low rubber prices

\begin{tabular}{|c|c|c|c|c|c|}
\hline \multirow{2}{*}{$\begin{array}{c}\text { Tahun } \\
\text { Year }\end{array}$} & \multirow{2}{*}{$\begin{array}{l}\text { Harga karet } \\
\text { Rubber price } \\
\text { (USD/kg) }\end{array}$} & \multicolumn{3}{|c|}{$\begin{array}{c}\text { Permintaan bibit karet pada tingkat } \\
\text { penangkar skala besar } \\
\text { Demand of rubber planting material at large } \\
\text { scale nursery grower } \\
(\%)\end{array}$} & $\begin{array}{c}\text { Permintaan bibit karet } \\
\text { pada tingkat penangkar } \\
\text { skala kecil } \\
\text { Demand of rubber } \\
\text { planting material at } \\
\text { small scale nursery } \\
\text { grower } \\
(\%)\end{array}$ \\
\hline & & $\begin{array}{l}\text { Permintaan } \\
\text { dari petani } \\
\text { swadaya } \\
\text { Demand } \\
\text { from self- } \\
\text { supported } \\
\text { farmers }\end{array}$ & $\begin{array}{l}\text { Permintaan } \\
\text { dari proyek } \\
\text { Pemerintah } \\
\text { Demand } \\
\text { from } \\
\text { Government } \\
\text { project }\end{array}$ & $\begin{array}{l}\text { Permintaan } \\
\quad \text { dari } \\
\text { perusahaan } \\
\text { perkebunan } \\
\text { Demand } \\
\text { from estate }\end{array}$ & $\begin{array}{l}\text { Permintaan dari petani } \\
\text { swadaya } \\
\text { Demand from self- } \\
\text { supported farmers }\end{array}$ \\
\hline $2011-2012$ & $\begin{array}{c}\text { tinggi } \\
(3,16-4,66)\end{array}$ & 36,7 & 61,7 & 1,7 & 100 \\
\hline $2013-2014$ & $\begin{array}{c}\text { rendah } \\
(1,79-2,32)\end{array}$ & 9,4 & 83,1 & 6,7 & 49 \\
\hline
\end{tabular}

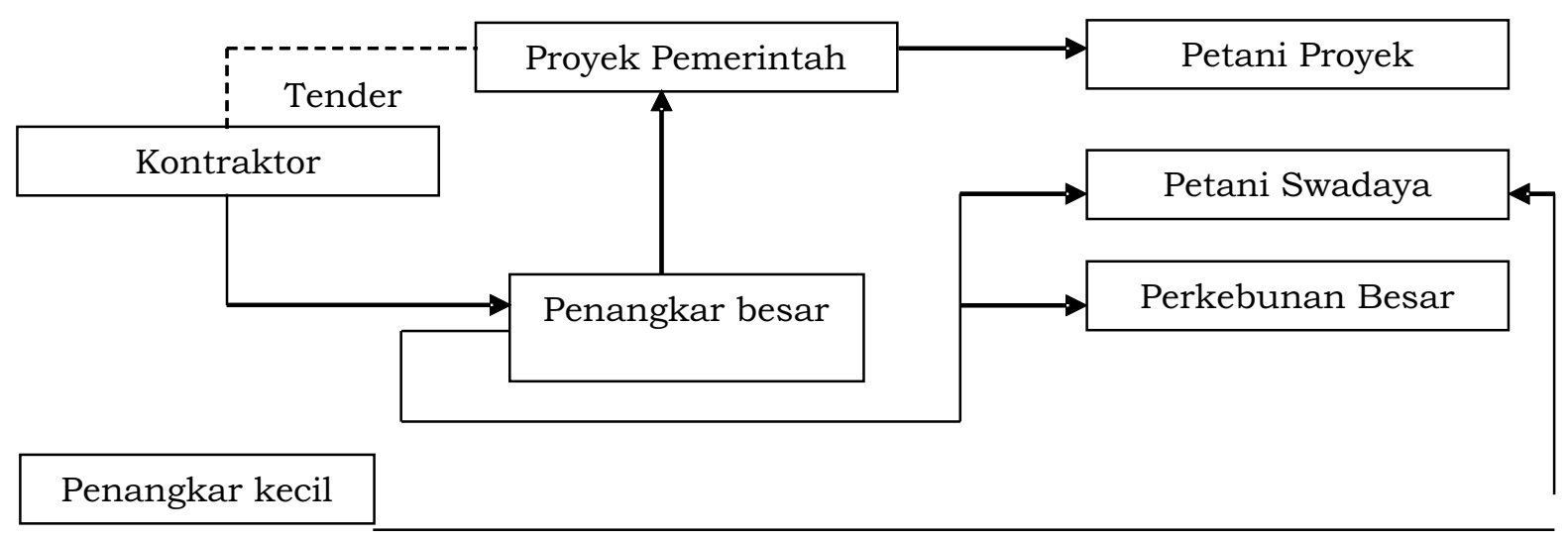

Gambar 4. Rantai pemasaran bibit karet di Provinsi Sumatera Selatan

Figure 4. Marketing chain of rubber planting material in South Sumatra Province

Harga bahan tanam di tingkat penangkar bervariasi. Harga bahan tanam berupa OMT pada tahun 2014 berkisar antara IDR 1.300 sampai IDR 1.800 di tingkat penangkar kecil sedangkan untuk penangkar skala besar harga OMT berkisar antara IDR 3.000 sampai IDR 6.000. Harga bibit polybag di tingkat penangkar kecil berkisar antara IDR 3.000 sampai IDR 5.000 sedangkan di tingkat penangkar besar, bibit polybag dijual kepada petani dengan harga berkisar IDR 4.000 sampai IDR 6.000. Harga bahan tanam bervariasi karena dipengaruhi faktor musim dan kondisi permintaan di lapangan. Pada saat menjelang musim tanam biasanya permintaan bibit meningkat sehingga harga bibit ikut naik sedangkan pada saat musim kemarau, jarang ada permintaan sehingga penangkar menjual bibit dengan harga relatif rendah 
dibandingkan pada saat musim tanam. Pada saat harga karet tinggi pada tahun 2011 2012, banyak petani yang membuka lahan untuk menanam karet. Permintaan bibit yang tinggi pada saat itu turut mempengaruhi harga bibit di tingkat penangkar. Pada tahun 2011 - 2012 bibit polybag rata-rata dijual kepada petani dengan harga IDR 4.500 sampai dengan IDR 7.000 .

\section{Kendala dalam Usaha Pembibitan}

Kendala yang dihadapi dalam usaha pembibitan sebagaimana yang diungkapkan oleh penangkar diantaranya adalah:

a) Pada umumnya penangkar kecil tidak memiliki modal untuk memenuhi persyaratan sertifikasi bahan tanam, mulai dari pengadaan biji bersertifikat sampai pemurnian kebun entres. Oleh karena itu penangkar kecil biasanya hanya mensuplai bahan tanam untuk petani swadaya, atau menjadi anggota kelompok atau mitra penangkar besar jika ingin mengisi proyek pemerintah.

b) Penyaluran bibit sering tertunda karena lahan belum siap tanam atau lahan masih bermasalah. Selain itu pada proyek pemerintah, waktu pelaksanaan proyek tidak sama dengan waktu penyaluran bibit sehingga penangkar harus menunggu. Dari pengalaman yang ada, seringkali bibit sudah mencapai payung 3 namun belum diambil karena waktu pelaksanaan proyek yang mundur. Hal ini menyebabkan mutu bahan tanam menurun dan akhirnya tidak terjual. Beberapa penangkar besar memanfaatkan bibit yang tidak terjual untuk ditanam sebagai tanaman entres atau ditanam pada kebun produksi milik mereka. Ada juga penangkar yang menjual murah atau memberi secara cuma-cuma kepada petani yang membutuhkan.

c) Jadwal penyiapan bibit sering terganggu karena berbagai sebab antara lain: waktu ketersediaan biji bergeser atau mundur karena pengaruh iklim, daya kecambah biji yang rendah, atau terjadi kemarau panjang sehingga waktu okulasi tertunda, okulasi gagal, sulit mencari tenaga okulator, dan sebagainya.

d) Harga bibit yang tidak dapat menyesuaikan dengan peningkatan biaya produksi. Meskipun harga PAGU dari proyek pemerintah mengalami kenaikan namun pihak rekanan yang memenangkan tender tidak menaikkan harga bibit sedangkan dari tahun ke tahun biaya produksi yang dikeluarkan penangkar terus meningkat.

e) Beberapa penangkar mengeluhkan permasalahan pelabelan untuk sertifikasi. Biasanya proses sertifikasi benih dilakukan oleh BPSBTP Provinsi Sumatera Selatan namun di Kabupaten Musi Rawas saat ini sudah ada perwakilan BPSBTP kabupaten yang dapat mengeluarkan label sertifikasi. Permasalahannya adalah pihak Dinas Perkebunan masih menginginkan label serifikasi dari BPSBTP Provinsi. Hal ini menurut penangkar adalah suatu hal yang menyulitkan dan tidak efisien karena seharusnya sertifikasi bisa dilakukan oleh BPSBTP Kabupaten namun masih harus mereka dapatkan dari BPSBTP Provinsi.

f) Permasalahan sumberdaya manusia yang terlibat dalam usaha pembibitan juga harus menjadi perhatian. Bisnis pembibitan karet membutuhkan sumberdaya manusia yang memiliki pengetahuan teknis pembibitan karet dan finansial yang mumpuni. Banyak penangkar yang menutup usahanya karena tidak mampu mengelola keuangan dengan baik.

\section{KESIMPULAN}

Bisnis pembibitan karet masih prospektif untuk dikembangkan. Potensi bibit yang tersedia di tingkat penangkar cukup besar mengingat perluasan lahan untuk kebun pembibitan masih terus 
dilakukan oleh penangkar. Permintaan bibit oleh petani sangat dipengaruhi oleh faktor musim dan harga karet. Turunnya harga karet menyebabkan jumlah permintaan bibit dari petani juga menurun. Usaha pembibitan di tingkat penangkar dengan skala besar pada saat harga karet rendah masih terbantu oleh permintaan dari proyek bantuan bibit karet pemerintah. Pada masa mendatang diharapkan agar usaha pembibitan dapat terus dilakukan mengingat permintaan bibit untuk peremajaan melalui dana pemerintah dan petani swadaya masih akan tetap ada. Selain itu kepada pihak Dinas Perkebunan agar dapat melakukan penyederhanaan prosedur dalam mengeluarkan label sertifikasi bagi penangkar.

\section{UCAPAN TERIMA KASIH}

Ucapan terima kasih diberikan kepada Bagian Komersialisasi Hasil Penelitian Balai Penelitian Sembawa dan BPSBTP Provinsi Sumatera Selatan serta penangkar bibit di Provinsi Sumatera Selatan atas bantuan data sehingga penelitian ini dapat berjalan dengan baik.

\section{DAFTAR PUSTAKA}

Bahrin, S. (2014). Prospek pengembangan karet Sumatera Selatan. Workshop Nasional Strategi Peremajaan Perkebunan Karet. Jakarta, Indonesia.

Balai Penelitian Sembawa. (2014). Laporan realisasi penjualan bahan tanam karet 2010-2013 Bagian Komersialisasi Hasil Penelitian Balai Penelitian Sembawa. Palembang, Indonesia: Balai Penelitian Sembawa.

Balai Pengawasan dan Sertifikasi Benih Tanaman Perkebunan. (2014). Data sertifikasi benih tanaman perkebunan 2008-2013. Palembang, Indonesia: BPSBTP.
Boerhendhy, I., Nancy, C., \& Amypalupy, K. (2009). Strategi pengembangan bahan tanam klon karet unggul. Prosiding Lokakarya Nasional Pemuliaan Karet (p.157-167). Batam, Indonesia: Pusat Penelitian Karet.

Dinas Perkebunan Provinsi Sumatera Selatan. (2013). Statistik perkebunan Sumatera Selatan tahun 2013. Palembang, Indonesia: Disbun Sumatera Selatan.

Gabungan Perusahaan Karet Indonesia. (2013). List of Members. Jakarta, Indonesia: GAPKINDO.

Nancy, C., \& Supriyanto. (2008). Pengelolaan dan penyaluran bahan tanam karet di Sumatera Selatan. Prosiding Lokakarya Nasional Agribisnis Karet 2008 (p. 117-129). Yogyakarta, Indonesia: Pusat Penelitian Karet.

Nancy, C., Lasminingsih, M., \& Supriadi, M. (2012). Perkembangan supply dan demand bahan tanam karet: tantangan penyediaan bibit karet bermutu. Prosiding Konferensi Nasional Karet (p.170-183). Yogyakarta, Indonesia: Pusat Penelitian Karet.

Siagian, N., Aidi-Daslin., \& Hadi, H. (2008). Potensi produksi klon unggul karet dan upaya pencapaiannya melalui penggunaan bahan tanam bermutu. Prosiding Lokakarya Nasional Agribisnis Karet 2008 (p. 95-116). Yogyakarta, Indonesia: Pusat Penelitian Karet.

Singapore Commodity Exchange Limited. (2014). Market Information [Grafik]. Diakses dari www.sgx.com 
Supriadi, M., Hendratno, S., Gozali, A. D., Nancy, C., Dereindera, R., \& Gouyon, A. (1992). The adoption of rubber cultivation technology by rubber smallholders in South Sumatera, Indonesia. Proceedings of IRRDB Socioeconomic Symposium (p. 47-61). Jakarta, Indonesia: IRRDB-IRRI.
Syarifa, L. F., Agustina, D. S., Nancy, C., \& Supriadi, M. (2012). Evaluasi tingkat adopsi klon unggul di tingkat petani karet Provinsi Sumatera Selatan. Jurnal Penelitian Karet, 30(1), 12-22. 